Tim Greenwood

\title{
Representations of Rulership in Late Antique Armenia
}

It should come as little surprise to discover that late antique Armenian literature preserves multiple constructions of rulership. Armenia experienced a series of major political, social and cultural transformations between the fourth and seventh centuries, as the twin powers of Rome and Persia confronted one another across this highly contested space. Represented as independent at the start of the fourth century, the Arsacid kingdom of Armenia was partitioned between the two powers in c. $387 \mathrm{CE}$, each installing a member of the Arsacid line as king. In the Roman sector, this practice was quickly discontinued but it persisted in the Persian sector until the deposition of king Artašēs in $428 \mathrm{CE}$. Thereafter every district of the former kingdom was under the notional control of Rome or Sasanian Persia and incorporated, to a greater or lesser extent, into their networks of government, administration and law. The balance of power remained remarkably stable for the following century and a half, with some four-fifths of historic Armenia under Persian hegemony, until the outbreak of war in 572 CE. From then on, as relations deteriorated, the situation became fluid. Both powers secured temporary control over swathes of Armenian territory - the Romans through negotiation in 591 and again in 630 as the Sasanian state imploded, the Persians in 607 after four years of warfare. ${ }^{1}$ The two decades after 640 witnessed a complex series of campaigns, raids and counter-measures undertaken by Roman, Armenian, and Arab forces. These culminated in Roman troops being driven westwards, beyond the river Euphrates, probably in $661 .^{2}$ Yet even this event did not mark the end of Roman engagement. Not only did Roman military operations across Armenia revive in 685 and continue for the next three decades; several compositions completed, translated, or reworked at this time contain representations of Roman rulership, conceptualised in historical and ecclesiastical terms, suggesting that this model of authority held meaning and significance in a contemporary Armenian context. $^{3}$

1 See G. Greatrex and S. N. C. Lieu, The Roman Eastern Frontier and the Persian Wars Part II AD 363630 (London and New York, 2002) for an overview; B. Dignas and E. Winter, Rome and Persia in Late Antiquity: Neighbours and Rivals (Cambridge, 2007) pp. 173-88.

2 There is no modern study of the Arab raids into Armenia after 640 CE; see W.E. Kaegi, Byzantium and the early Islamic conquests (Cambridge, 1992), pp. 181-204. J.F. Haldon, The Empire That Would Not Die: The Paradox of Eastern Roman Survival, 640-740 (Cambridge MA, 2016), refers regularly to Armenia but its two extended excurses on regional variation and resistance explore North Africa and Italy, at pp. 197-214.

3 For a new study of Islamic rule over Armenia, see A. Vacca, Non-Muslim Provinces under Early Islam: Islamic Rule and Iranian Legitimacy in Armenia and Caucasian Albania (Cambridge, 2017). We await new studies of the Armenian and Byzantine perspectives on this critical period, but for

2 OpenAccess. (C) $2021 \mathrm{Tim}$ Greenwood, published by De Gruyter. (cc))BY-NC-ND This work is licensed under the Creative Commons Attribution-NonCommercial-NoDerivatives 4.0 International License. 
On the basis of the above, the substantial canon of late antique Armenian literature seems to offer a perfect vantage point from which to trace the reception of Persian and Roman traditions of rulership over an extended period of time. Perhaps inevitably it is not as straightforward as it appears and three particular characteristics of Armenian literary tradition need to be outlined. In the first place, none of the surviving original compositions in Armenian derive from the Roman sector of Armenia, at least not obviously so. This is not to say that such works did not circulate within the Roman world. Writing in the middle of the sixth century, Procopius refers to a 'History of the Armenians' at the start of his Wars and Garsoïan has drawn attention to parallels between episodes in this section of his narrative and the Armenian text known as the Buzandaran Patmut 'iwnk' or Epic Histories. ${ }^{4}$ But it remains the case that the traditions and attitudes of those Armenians settled within the frontiers of the Roman Empire have not been preserved in Armenian literature. ${ }^{5}$ As a result, all the surviving works come from the Persian sector and tend to be suffused with representations of Persian rulers rather than Roman emperors. As discussed below, emperors are usually distant, silent figures, to whom appeals can be made in times of emergency, but who remain on the margins of the narrative. This only changes in the middle of the seventh century. Secondly, all the surviving texts, whether historical, hagiographical or philosophical in character, were composed or compiled by Christian authors and preserved through ecclesiastical or monastic institutions. They reflect a complex blend of cultural and linguistic traditions but we need to remember that they attest an overwhelmingly clerical mindset and perspective. This is not to suggest they do not contain a wide range of representations. Although Sasanian šahanšahs could be represented as impious fire-worshipping persecutors of their Armenian subjects - imagined as a community of faithful believers and ready to die for their faith if need be - they could also be portrayed as legitimate rulers and even closet Christians. As we shall see, the good Persian ruler could be constructed as one who respected Armenian religious traditions and listened in person to the petitions of his Armenian subjects; the bad Persian ruler was one who sought to extirpate those religious practices and ignored those appeals. It should be noted, however, that this religiously charged interpretation of the relationship between Persian rulers and Armenian subjects sprang primarily from the attitudes and concerns of the Christian Armenian authors and that the relationship had political, social and military dimensions as well, even if these are not as prominent in the narratives. And thirdly, since the invention of the Armenian script - the work of the divinely-inspired Maštoc ${ }^{\circ}$ - did not occur until the start of the fifth century and the ear-

the potential, see M. van Esbroeck, "La politique arménienne de Byzance de Justinien II à Léon III", Studi Sull'Oriente Cristiano 2 (2) (1998) pp. 111-20.

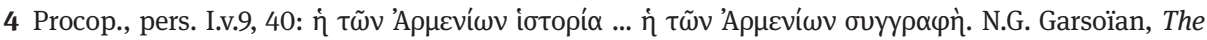
Epic Histories (Buzandaran Patmut iwnk') (Cambridge MA, 1989) pp. 10, 301-2 (IV.54).

5 For a rare voice from this region, preserved by Gregory of Tours, see T.W. Greenwood, “Armenia”, in The Oxford Handbook of Late Antiquity, ed. S.F. Johnson (Oxford, 2012) pp. 115-19. 
liest original Armenian composition, Koriwn's Life of Maštoc', is conventionally dated to the middle of that century, it follows that those works which portray the kingdom of Arsacid Armenia were written after it had disappeared. ${ }^{6}$ Nothing survives of how the Arsacid kings represented themselves; instead we are left with narratives of uncertain provenance assembled and preserved in later compilations. This is not to argue that it is impossible to recover any reflection of Arsacid kingship. The Buzandaran Patmut iwnk' offers considerable insight into fourth-century affairs. But we need to recognise that it does so from a later fifth-century perspective and that it will have been shaped, to some degree at least, by the interests and concerns of its compiler.

Since it is not feasible to analyse representations of rulership across the gamut of late antique Armenian literature, this study is limited for the most part to four of the principal Armenian historical texts: the Buzandaran Patmut 'iwnk' (compiled in the third quarter of the fifth century), the History of Eazar P'arpec $i$ (composed c. 500 $\mathrm{CE}$ ), the History of Ełišē (completed during the last third of the sixth century) and the History attributed to Sebēos (assembled in $655 \mathrm{CE}$, with updating scholia inserted in $661 \mathrm{CE}$ ). It does not extend to the famous - and famously controversial - History of Movsēs Xorenac $i$. Analysing changes in the representation of rulership across several texts requires confidence in the chronological sequence of those works. The date of Movsēs' sophisticated text remains highly contested..$^{7}$ Including it risks invalidating the results obtained and it has therefore been left out.

The study is divided into three sections. After a brief introduction to each work, the use and frequency of certain terms will be established, including the context or contexts in which they are found. The results will be presented and assessed on a text by text basis. ${ }^{8}$ The second section compares how Persian, Roman and Armenian

6 G. Winkler, Koriwn's Biographie des Mesrop Maštoc', Überzetzung und Kommentar, OCA 245 (Rome 1994); J.-P. Mahé, “Koriwn, La Vie de Maštoc", Traduction annotée”, REArm 30 (2006-2007) pp. $59-97$.

7 For a thorough overview, see N.G. Garsoïan, "L'Histoire attribuée à Movsēs Xorenac i: Que reste-t-il à en dire?”, REArm 29 (2005) pp. 29-48.

8 Buzandaran, P'awstosi Buzandac woy Patmut iwn Hayoc $i$ čors dprut iwns (Venice, 1933), repr. in Matenagirk' Hayoc' 5th Century, vol. 1 (Ant'ilias, 2003) pp. 277-428; Łazar P’arpec i, Patmut 'iwn Hayots' ew T'ult' ar Vahan Mamikonean, ed. G. Tēr-Mkrtč'ean and S. Malxasean (Tiflis, 1904; repr. Delmar, NY, 1985), repr. in Matenagirk' Hayoc 5th Century, vol. 2 (Ant'ilias, 2003) pp. 2201-2375; Ełišē, Etišèi vasn Vardanay ew Hayoc ' paterazmin, ed. E. Tēr Minasyan (Erevan, 1957), repr. in Matenagirk' Hayoc ${ }^{\circ}$ 5th Century, vol. 1 (Ant ilias, 2003) pp. 521-764; Sebēos, Patmut iwn Sebēosi, ed. G.V. Abgaryan (Erevan, 1979), repr. in Matenagirk' Hayoc' 7th Century, vol. 4 (Ant'ilias, 2005) pp. 453-565. To give an impression of relative length, Buzandaran comprises 152 pages of the reprinted edition, Eazar's History extends to 175 pages, Ełišē's to 244 pages and Sebēos' to 113 pages. Although Sebēos' History is clearly shorter than the others, these figures are not exactly comparable. The critical apparatus supporting Ełišè's text is more substantial since it is preserved in multiple manuscripts, unlike the other three works; this has the effect of reducing the number of words per page. Eazar and Sebēos are both preserved only through the same manuscript, Matenadaran 2639, copied in $1672 \mathrm{CE}$. There is presently no means of establishing absolute word lengths. 
rulers were represented across these compositions and explores why these representations change. Particular attention will be given to the portrayal of Sasanian šaha$n s ̌ a h s$ in the History of Łazar P'arpec 'i, and how and why this differs from that found in Ełišè's History. This work was based upon Łazar's account of the rebellion and martyrdom of Vardan Mamikonean in $451 \mathrm{CE}$ but it projects a noticeably different image of Yazdgird II and reconfigures the relationship between Persians and Armenians. Finally the third section analyses how Sebēos and other seventh-century Armenian writers conceptualised rulership following the collapse of Sasanian Persia and the emergence of a new and dynamic polity in the form of the Islamic caliphate.

\section{Terminology}

There are two words in Classical Armenian for 'king': upfuy/ark'ay (Gk. äpxwv, ruler) and (puquinp/t'agawor (Mid. Pers. ${ }^{*} t a \bar{g}$-bar, 'bearing the crown,' but with Arm.-wor, Indo- European *-bhoros, substituted for the second element). ${ }^{9}$ If we examine Astuacaturean's concordance to Zōhrapean's edition of the Armenian Bible for their distribution and context, we find that arkay appears more frequently in the Old Testament than tagawor overall although the difference is not substantial (1303 and 1077 occasions respectively). ${ }^{10}$ Since the Armenian Bible is composite, in the sense that each book has its own distinctive textual history, these totals are not statistically meaningful. ${ }^{11}$ Nevertheless it may be significant that arkay is used much more frequently in the six historical books (1 and 2 Samuel, 1 and 2 Kings and 1 and 2 Chronicles) than tagawor (on 794 occasions as opposed to 215). ${ }^{12}$ Conversely, tagawor occurs 60 times in Psalms whilst arkay appears just once. Moreover tagawor is used exclusively in Proverbs (35 instances), Ecclesiastes (10), Lamentations (5), Jonah (2), Micah (4), Nahum (1), Habbakuk (1) and Malachi (1). King David is titled ark'ay and tagawor - indeed 2 Samuel 5:3 applies them both to David - but the same is true of Saul and the king of Moab, suggesting that the attributes of divinely sanctioned kingship are not represented through one rather than the other. ${ }^{13}$ If we turn to the New Testament, we find a different frequency and distribu-

9 H. Ačarean, Hayerēn armatakan bararan, rev. ed. 4 vols. (Erevan, 1971-1979) I, pp. 345-7 and II, pp. 135-7 respectively; R. Schmitt, "Armenia and Iran iv: Iranian influences in Armenian Language, 5. Linguistic Analysis. Morphology”, Encyclopædia Iranica, online edition, 2018, available at https:// www.iranicaonline.org/articles/armenia-iv (accessed 05 June 2018).

10 T'. Astuacaturean, Hamabarbar Hin ew Nor Ktakaranac' (Jerusalem, 1895); Astuacašunč matean Hin ew Nor Ktakaranac', ed. Y. Zōhrapean (Venice, 1805).

11 For an overview of the present state of research, see C. Cox, "1.4.7 Armenian Translations", in Textual History of the Bible, Vol 1 A, ed. A. Lange and E. Tov (Leiden, 2016) pp. 370 -5. Consulted online on 05 June 2018 http://dx.doi.org/10.1163/2452-4107_thb_COM_0001040700.

12 In the Armenian Bible, 1-2 Samuel and 1-2 Kings are identified as 1-4 Kingdoms, T'agaworut'eanc; 1-2 Chronicles are titled 1-2 Supplements, Mnac'ordac:

132 Kgdms 5:3 '... uxt ark'ay Dawit'... ōcin zDawit' t'agawor...'. 
tion. Here arkay is less commonly used (25), is limited, with one exception (2 Cor 11:32) to the Gospels and Acts and applied predominantly to kings of Israel and Judea, including Herod; tagawor on the other hand is three times more commonly used than arkiay (76) and is distributed throughout the New Testament in a wider range of contexts, including many related to Jesus. Clearly there is much more research of this type that could be undertaken but it does not seem that ark'ay and $t^{\prime} a$ gawor were applied consistently, nor that they imply different forms or qualities of kingship, either earthly or heavenly.

Let us now turn to the four historical compositions. Scholarly convention used to dictate that a work covering the history of Arsacid Armenia from the death of king Trdat in c. 330 CE to the partition of the kingdom in c. 387 should be attributed to one P'awstos Buzandac i, sometimes called Faustus of Byzantium. As a result of Perikhanian's etymological research, the same work is now recognised as an anonymous composition properly titled Buzandaran Patmut 'iwnk' or Epic Histories. ${ }^{14}$ This revised title suits the contents which possess undeniably heroic dimensions. In her magisterial study of the text, Garsoïan identified two main collections of stories within the composition which she termed the 'Geste of the Aršakuni' and the 'Geste of the Mamikonean. ${ }^{15}$ These had been fused with a third strand of ecclesiastical history, focused largely on the sequence of patriarchs from the family of Saint Grigor the Illuminator. Garsoïan did not define this explicitly as a 'Geste of the Gregorids' and the question of the form in which this material circulated and how it came to lodge in the Buzandaran is left open. This is certainly not the occasion for a wholesale reappraisal of the work but its date of composition is very significant for this study and so merits brief attention. Garsoïan used several separate chronological markers to support her view that the Buzandaran was assembled in the $470 \mathrm{~s} .{ }^{16}$ She maintained that the reference to a time when the family of Saint Grigor would no longer lead the Armenian church points to a date after 438 CE when the last in the line, Saint Sahak, died. The consecration of Vač è Mamikonean and the Armenian dead by the patriarch Vrt'anēs recalls the commemoration of Vardan Mamikonean and his companions following the battle of Awarayr in $451 \mathrm{CE} .{ }^{17}$ Several passages from Koriwn's Life of Maštoc', identified as being composed between 443 and $451 \mathrm{CE}$, appear to inform passages in the Buzandaran. And Łazar P'arpec' $i$, writing in c. 500 CE, identifies the second written history of Armenia as that of one P'awstos of Buzand, confirming both that this work was in existence by the turn of the century and that the misunderstanding over its authorship went back to this time. ${ }^{18}$ To these, one could add that the editorial

14 A.G. Perikhanian, "Sur arm. buzand", in Armenian Studies in Memoriam Haïg Berbérian, ed. D. Kouymjian (Lisbon, 1986) pp. 653-8.

15 Garsoïan (cf. fn. 4) pp. 32-5.

16 Garsoïan (cf. fn. 4) pp. $10-11$.

17 Buzandaran (cf. fn. 8) III.11; Garsoïan (cf. fn. 4) pp. 80-1.

18 Łazar (cf. fn. 8) section 3.2; tr. R.W. Thomson, The History of Eazar P'arpec i (Atlanta GA, 1991) p. 36. See also Łazar 15.5; tr. Thomson History, p. 60, describing Saint Nersēs cursing Aršak for the 
decision to include so many episodes of conflict between Persians and Armenians, and in particular Vasak Mamikonean's killing of the head-groom of the Persian king's stables for insulting the Armenian king, suits the context of mutual distrust and hostility which persisted after $451 \mathrm{CE}$ but would have jarred uncomfortably with the lived experience of contemporaries after 484, when the parties were reconciled. ${ }^{19}$ Although narrowing the parameters for the date of composition to the $470 \mathrm{~s}$ is not further substantiated by Garsoïan, we can be confident that the Buzandaran was compiled at some point between the mid-450s and early 480 s.

Studying the terminology of the composition as a whole, we find that tagawor is employed over twice as often as ark'ay (on 584 occasions as opposed to 264).$^{20}$ Both terms are applied to both Persian and Armenian kings: t'agawor is used for kings of Armenia on 334 occasions and for kings of Persia on 167 occasions; ark ay is used for kings of Armenia on 174 occasions and for kings of Persia on 78 occasions. There are multiple instances when we find tagawor and ark'ay being applied to the same figure in successive sentences. ${ }^{21}$ There is nothing to indicate a hierarchy of kingship on the basis of the terms used, or to put it another way, the choice of term employed for king does not denote a different quality to that kingship. There are two features, however, which stand out in respect of the Roman ruler. Firstly the title lujup/kaysr (Gr.

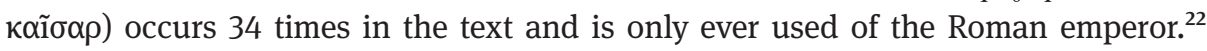
Secondly the Roman ruler is also termed tagawor, on 74 occasions, but ark'ay on just two occasions. This suggests that Persian and Armenian kings were treated in broadly similar ways within the composition but that Roman rulers were differentiated. Three other features also merit attention. In the first place, the Roman ruler is invariably titled kaysr, emperor, or t'agawor Yunac', usually translated as 'king of the Greeks' but literally 'of the Ionians' (Mid. Pers. Yayna). ${ }^{23}$ Only once (III.10) is he called kaysr Horomoc', 'emperor of the Romans' and never king of the Romans; indeed as Garsoïan noted, 'Roman' occurs only three times in the whole composition. ${ }^{24}$ Secondly the Sasanian rulers are uniformly titled t'agawor/ark'ay Parsic', just as Armenian kings are t'agawor/ark'ay Hayoc'. The term Unpf/Arik' (Genitive: Uphug/

death of his nephew Gnel 'as it is written in the Second history in the fifteenth chapter'; the equivalent passage occurs in Buzandaran at book IV chapter 15.

19 Buzandaran (cf. fn. 8) IV.16; Garsoïan (cf. fn. 4) pp. 146-7. The groom called him aycic Hayoc' ark'ay, king of the Armenian goats, and invited him to "Come, sit down on a bundle of grass"! 20 All the figures are based on my own textual scrutiny, noting down individual instances as I read through the Armenian text. They are not the product of a digital search. Although the absolute totals may prove to be incorrect, the margin of error will be small.

21 See for example Buzandaran (cf. fn. 8) III.16: ar ark'ayn... t’agaworn; IV.1: i ark'ayin Parsic'... t'agaworn Parsic Nerseh; IV.20: Šaphoy ark'ayin Parsic'... Šapuh t'agaworn Parsic'; IV.53: Šapuh ark'ay Parsic'... t'agaworin Parsic' Šaphoy; V.44: araji Aršakay ark'ayi... zt'agaworn Aršak.

22 Garsoïan (cf. fn. 4) pp. 537-8 includes kaysr in her appendix of technical terms but does not identify how many times it is used, nor does she consider either ark'ay or t'agawor in her study.

23 Garsoïan (cf. fn. 4) p. 375.

24 Buzandaran (cf. fn. 8) III.10: Kostandianosi kayser Horomoc'; Garsoïan (cf. fn. 4) pp. 375, 402. 
Areac), sometimes translated as Aryan but perhaps more helpfully understood as 'those of Ėrānšahr,' the realm of Ērān, is found on just seven occasions, four of which attest a military context. It is never employed in association with either term for king. Finally t'agaworut iwn, meaning kingdom, kingship or reign, occurs 46 times, always in a terrestrial, worldly context (Armenian 35, Persian 7, Roman 2 and Ërān 2); ark'ayut iwn appears on seven occasions and only in relation to the kingdom of heaven.

Unlike the Buzandaran, we are much better informed about the circumstances in which Łazar P'arpec 'i’s Patmut iwn Hayoc'/History of Armenia came into being. Łazar states that he was commissioned by Vahan Mamikonean to write a historical composition, picking up from where the Second Book - that is, the Buzandaran - had ended and taking the narrative down to the point at which Vahan was appointed marzpan of Armenia, shortly after peace had been agreed in $484 \mathrm{CE} .{ }^{25}$ At the invitation of Vahan, with whom he had been brought up as a child, Eazar was put in charge of the religious community at the cathedral of Vałaršapat. ${ }^{26}$ Subsequently, he was accused of heresy and forced to write a letter to Vahan from exile in Amida vigorously defending himself, following which he was reinstated. ${ }^{27}$ When these details are taken together, it seems most likely that Łazar's History was composed in the last decade of the fifth century.

The work is divided into three books of unequal length. ${ }^{28}$ Book I covers the period from the partition of the kingdom to the death of Saint Sahak in 438 CE. Book II addresses the context in which rebellion broke out in 450 CE under Vardan Mamikonean, the battle of Awarayr itself and its aftermath, focusing at length on the fates of the Armenian nobles and clerics who had been taken captive. The final book considers the circumstances of Vahan's own rebellion thirty years later in $482 \mathrm{CE}$ and how he and his supporters managed to negotiate a settlement with the Persian king Vałarš in 484. Eazar is careful to acknowledge several of his sources, written and oral. He reveals, for example, that he learned about the imprisonment of the nobles and the martyrdoms of the holy clerics outside the city of Nišapur from Aršawir Kamsarakan, the lord of Aršarunik', who in turn had heard about them from a blessed Xužik, a merchant from Xužastan who was a Christian and who spoke Armenian. ${ }^{29}$ Given the terrible reputation that Xužiks later came to have in Armenian sources as purveyors of 'Nestorian' teaching, this positive image is striking. Book III is devoted specif-

25 Łazar (cf. fn. 8) 4.1-6; Thomson (cf. fn. 18) pp. 37-8.

26 Łazar (cf. fn. 8) Letter, 7, 21-31; Thomson (cf. fn. 18) pp. 248-50.

27 Eazar (cf. fn. 8) Letter, 8-14; Thomson (cf. fn. 18) pp. 248-9. The letter was delivered to Vahan by Hamazasp Mamikonean. Since Amida was besieged and captured by the Persian king Kavadh in 502 CE and remained under Persian control until the conclusion of the conflict in $505 \mathrm{CE}$, it is likely that Łazar sought refuge there before 502.

28 Łazar (cf. fn. 8). Using the reprinted edition, book I comprises 36 pages, book II 66 pages, and book III 73 pages.

29 Łazar (cf. fn. 8) 57.10; Thomson (cf. fn. 18) p. 151. The Xužik features regularly in the narrative. 
ically to the career of his patron, Vahan Mamikonean, and there is every reason to believe that this was composed by Łazar himself, giving it a particular value. This being so, we shall analyse the terminology book by book.

In book I, we find that kings of Armenia are almost always titled tagawor (39 occasions) rather than arkay (3) but that kings of Persia are titled t'agawor (14) and arkay (18) in almost equal measure. The Roman ruler is consistently tagawor (8) and never ark'ay or kaysr; on seven occasions he is titled tagawor Yunac'. Thereafter the kings of Armenia vanish from the narrative, which is only to be expected given the demise of the kingdom in 428 CE. In book II, it is now the Sasanian kings of Persia who are titled tagawor, on 82 occasions, compared with just 16 instances of arkay. It is significant, however, that six of these 16 employ the title ark 'ayic' ark'ay, an Armenian calque on the familiar Iranian title 'king of kings' (Mid. Pers.

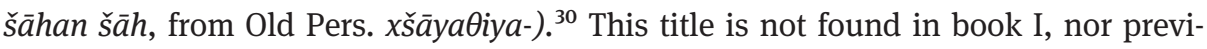
ously in the Buzandaran. Moreover all six are found in direct speech. In contrast, the equivalent t'agawor t'agaworac' occurs twice, both times in relation to God. This corresponds with its Biblical usage; at 1 Timothy 6:15 and Revelation 17:14, t'agawor t'agaworac is applied to God and the Lamb of God respectively. ${ }^{31}$ The Roman ruler is referred to as tagawor (4) and kaysr (10) but not arkay. In book III, kings of Persia are again titled t'agawor more frequently than ark'ay (91 and 19 respectively) but here it is striking that 14 of the 19 use the form ark'ayic ark'ay and all except one of these occurs in direct speech. The Roman ruler features just twice, once as tagawor, and once as kaysr. ${ }^{32}$ Finally whilst t'agaworut iwn appears 43 times, again only in a worldly context (Armenian (16) Persian (22) and others five), ark ayut iwn appears on eight occasions, again only in connection with the kingdom of heaven and the heavenly realm.

There is however one further important development. In book I, we find three instances of t'agawor Areac', 'king of the Aryans' or 'king of Ērān,' together with one further use of this collective. In Book II, again there are three instances of t'agawor Areac', but a new title appears, untp Untıug/tèr Areac', 'lord of Ėrān. ${ }^{33}$ It only occurs four times but it could have been used in book I and was not. In fact, there are 49 occasions on which Arik' appears in book II, including seven references to awagnwoyn Areac', 'the nobles of Ērān,' and four instances of the phrase Areac' ew Anareac', 'of Ërān and not-Ērān.' These patterns mature in book III. This contains 106 references to Arik', of which three qualify tagawor, six awagnwoyn and two

30 Schmitt (cf. fn. 9), "3. Layers of Iranian Borrowings".

31 Ezra 7:12 Artašēs t'agawor t'agaworac', but see Ezekiel 26:7 zNabugodonosor or ē ark'ay ark'ayic' and Daniel 2:37 du [Nabugodonosor] es ark'ay, ark'ayic' ark'ay.

32 t'agaworn Yunac Lewon: Łazar (cf. fn. 8) 63.15; Thomson (cf. fn. 18) p. 165: ar kaysr: Łazar (cf. fn. 8) 67.9; Thomson (cf. fn. 18) p. 175.

33 For a discussion of Arik' (Old Pers. Ariya- and Avestan Airiia) and its borrowing in the Achaemenid era, see Schmitt (cf. fn. 9) "3. Layers of Iranian Borrowings”. 


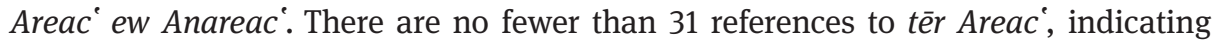
that this title held particular significance for Eazar. We shall return to this below.

The relationship between the Histories of Łazar and Ełišē has long been contested but this study accepts Thomson's proposition, following Akinean and Kiwlēsērean, that 'the History of Ełišē [is] more easily understood as an expansive adaptation of Łazar than the latter's work as an abbreviation of Ełišē. ${ }^{34}$ It draws predominantly on book II of Łazar's composition, covering Vardan Mamikonean's rebellion, the battle of Awarayr and its aftermath. It concludes with the imminent release of the remaining prisoners, in the fifth year of king Peroz (463/4 CE) and a study of the virtues of the wives and widows back in Armenia. ${ }^{35}$ These feature briefly at the opening of Łazar's book III but Ełišē's composition contains no hint of Vahan Mamikonean's subsequent revolt, nor the final reconciliation. ${ }^{36}$ This creates a different ending, one that leaves open whether or not the prisoners are returned. In terms of its date of composition, Akinean argued for a complex two-stage process, according to which the first version was composed in Constantinople in the aftermath of the rebellion of the second Vardan Mamikonean in $572 \mathrm{CE}$ and was subsequently reworked in c. 640; according to Akinean, only this second revised version survives. As Thomson noted, this seems unnecessarily complicated; furthermore it does not consider the circumstances under which the second version was produced. ${ }^{37}$ On the other hand, postulating a late sixth-century date fits other features of the text, notably its clear debt to the Armenian translation of several works by Philo, especially De Jona and De Vita contemplativa. ${ }^{38}$ It would also account for several parallels with the Ecclesiastical History of John of Ephesus, a work which extends to 589 CE. These include Ełišè's representation of Yazdgird II comparing the merits of different belief systems in his realm, specifically Zoroastrian, Chaldean and Christian teachings, usmunk; John's Khusro I is depicted doing something very similar. Moreover Ełišē's Yazdgird II even asserts that his father (Vahram V, 421-439 CE) had examined all the usmunk' and found the Christian tradition, ōrēnk to be more sublime, veh, than all the others. ${ }^{39}$ This notion of the Persian court as a place of intellectual discourse and religious debate is a feature of the later Sasanian era and supports a later sixth-century context for Ełišē's History. ${ }^{40}$

34 R.W. Thomson, Elishē History of Vardan and the Armenian War (Cambridge MA and London, 1982) p. 27.

35 Etišē (cf. fn. 8), Anuank Naxararac'/Names of the Naxarars, pp. 759.73-764.109; Thomson (cf. fn. 34) pp. $243-8$.

36 tazar (cf. fn. 8) 61.7-11; Thomson (cf. fn. 18) p. 161.

37 Thomson (cf. fn. 34) pp. 23-4.

38 Thomson (cf. fn. 34) pp. 21-2; S.P. Cowe, “Etišē's 'Armenian War' as a metaphor for the Spiritual life”, in From Byzantium to Iran. Armenian Studies in honour of Nina G. Garsoïan, ed. J.-P. Mahé and R.W. Thomson (Atlanta, GA, 1997) pp. 350-2.

39 Ełišē (cf. fn. 8) 3.227-33; Thomson (cf. fn. 34) pp. 134-5.

40 See J.T. Walker, The Legend of Mar Qardagh (Berkeley and Los Angeles, 2006) pp. 172-80; and A. Cameron, Dialoguing in Late Antiquity (Cambridge MA, 2014) pp. 23-38. 
Ełišē's use of terminology differs from that of Łazar. The kings of Persia are identified as t'agawor more frequently than ark'ay (103 as against 24); strikingly every single use of t'agawor is anonymous. Out of the 24 occurrences of ark'ay, ark'ayic'ark'ay occurs seven times, always in association with a named figure. Five of these have a temporal association, either general or specific. Of the remaining 17, all bar one are anonymous. In comparison the Roman ruler is termed tagawor Yunac once and kasyr on six occasions; he is never titled arkay. Once again, the use of arkayut iwn (7) is limited to the heavenly realm; t'agaworut iwn appears just 5 times, twice when establishing a Persian regnal year and once in an Armenian context. Finally Arik occurs on 13 occasions but never in conjunction with rulership; tèr Areac' has seemingly vanished from the lexicon. There is a single reference to awagnwoyn Areac and three references to Areac' ew Anareac:

Unlike Ełišē's composition, the History attributed to Sebēos can be situated very precisely in time. Its compiler - almost certainly the anonymous bishop who defied Constans II during a service in Dvin by refusing to take communion and who was then summoned by the emperor for a private meeting to explain his actions - completed his work in the first months of $655 \mathrm{CE} .{ }^{41}$ Six years later, he added several short notices into the margins of the manuscript, thereby disrupting the sequence of the final notices. There is nothing to suggest any later interference with the work, leaving it as a precious compilation of materials, assembled in the middle of the seventh century.

Looking at the frequency of the chosen titles across the composition, we find that kings of Persia are identified as ark'ay more frequently than tagawor (99 as opposed to 70) although there are just three occasions when he is titled ark'ayic ark'ay, all in direct speech. The Roman ruler is titled tagawor (106), kaysr (36) and, for the first time, arkiay (21). It is striking that arkiay is only used for a Roman ruler following the death of Khusro II in February 628, after which Persia was convulsed by civil war. However although he is often t'agawor Yunac' (19 instances), he is never t'agawor Horomoc', nor ark'ay Horomoc', king of the Romans. Once again, the use of ark'ayut iwn (2) is limited to the heavenly realm; tagaworut'iwn appears 92 times in both a Persian (47) and a Roman (32) context, although it is associated specifically with Horovmk'/Horomk' (Genitive: Horomoc) on just two occasions. ${ }^{42}$ Arik' also appears twice, once in the phrase tagaworut iwn Areac:

There is one further expression of rulership to trace, albeit briefly. How are caliphs titled? In Sebēos, the caliph is titled ark'ay Ismayeli (6). It may simply be coincidental but the first use of this title appears in the sentence after that recording the final destruction of the kingdom of the Persians..$^{43}$ We should not place too much

41 Sebēos (cf. fn.8) chapter 49.18-43; tr. and comm. R.W. Thomson and J.D. Howard-Johnston, The Armenian History attributed to Sebeos (Liverpool, 1999) pp. 141-2. For the date, see J.D. Howard-Johnston, Witnesses to a World Crisis (Oxford, 2010) p. 74.

42 Sebēos (cf. fn. 8) 47.8 and 49.56.

43 Sebēos (cf. fn. 8) 48.11-12. 
stress on the selection of ark'ay because tagawor is also used for the caliph on four occasions, the first of which refers to tagaworn noc'a Amr, 'their king Amr. ${ }^{44}$ The caliph is never called king of the Saracens, nor of the Tačikk'/Arabs nor of the Hagar$a c^{\prime} i k^{\prime} /$ Hagarenes, nor are Muslims yet called aylazgik'/foreigners, the term used for them by later Armenian writers, echoing the Old Testament term for Philistines. If we turn to book II of Patmut iwn Aluanic/History of Caucasian Albania which possesses a core of seventh-century materials assembled probably in the 680s, we

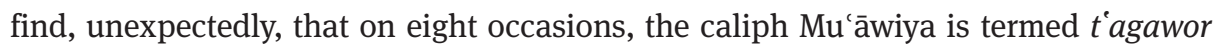
harawoy (or harawaynoy), 'the king of the south,' thereby equating him with the figure who features so prominently in Daniel chapter $11 .{ }^{45}$ Here we can see a contem-


the Last Times. Therefore, unlike the anonymous compiler of the History attributed to Sebēos, who employed a title stressing descent from Ishmael, the writer of this later work used a title reflecting his own interpretation of who the caliph was. It is only at the start of the eighth century that we find an Armenian source referring to the caliph - specifically 'Abd al-Malik b. Marwān - as amirmomin, an Armenian transliteration of the Arabic amir al-mu'minim, commander of the faithful. ${ }^{46}$

\section{Comparative Analysis}

Acknowledging that all the works are compilations, and so prone to internal variation, nevertheless a number of patterns may be discerned. The most common terms for rulers are tagawor and arkay, both meaning king, with tagawor being used more frequently in all four texts. The choice of term does not appear to denote a particular quality or imply a particular meaning. Both are applied to kings of Armenia and Persia and there are many instances when the same figure is titled with first one and then the other in close proximity. One weak pattern of distribution is that ark ay seems to be preferred in direct speech. The only consistently strong pattern is that the Roman emperor is usually titled tagawor and almost never arkay in the first three texts (twice in the Buzandaran, never by Łazar or Ełišē). ${ }^{47}$ This changes in the History attributed to Sebēos where Roman rulers are for the first time consis-

44 Sebēos (cf. fn. 8) 42.92. Amŕ: 'Umar b. al-Khațāāb (23 August 634-3 November 644).

45 Movsēs Dasxuranc i/Kałankatuac i, Patmut ¿iwn Atuanic' Ašxarhi, ed. V. Arak'elyan (Erevan, 1983), repr. in Matenagirk' Hayoc '10th Century, vol. 15 (Ant ilias, 2012) pp. 25-437. For a recent evaluation of the seventh-century core, see Howard-Johnston (cf. fn. 41) pp. 108-113. I have exploited one of the clusters of material in book II (chapter 18-28) comprising extracts from a eulogising biography of Juanšēr, prince of Ałuank'.

46 Patmut iwn Atuanic (cf. fn. 45) III.5.1: Tiezerakal Abdlayi amirmomnoy.

47 This is corroborated by a handful of seventh-century Armenian inscriptions: T.W. Greenwood, “A Corpus of Early Medieval Armenian Inscriptions”, DOP 58 (2004) pp. 27-91. At Bagaran (A.3), completed in 629 CE, Khusro II is titled arkay; at Ałaman (A.4), Bagavan (A.5) and Mren (A.6), all dating from the 630s, Heraclius is titled tagawor. 
tently titled arkay. This only occurs after the passages reporting the demise of Khusro II in $628 \mathrm{CE}^{48}$

In addition to these terms, there are three titles which are applied exclusively to either Persian or Roman rulers. In book II and book III of Łazar's History, the Persian ruler is identified as ark 'ayic ark'ay, 'king of kings,' on 20 occasions, all but one in direct speech. In Ełišè's History, this title is used on seven occasions and is associated strongly with dating clauses. Sebēos employed it on just three occasions, again always in direct speech. It is never used in the Buzandaran. Secondly, the term ter Areac', 'lord of the Aryans' or 'lord of Ėrān,' occurs four times in book II of Łazar's History and 31 times in book III, always with reference to the Persian king. It is not found in any of the other texts. This notion of Aryan, those of Ērān, is particularly prominent in Łazar's History, being mentioned on four occasions in book I, 49 occasions in book II and 106 occasions in book III. By comparison it appears just 7 times in the Buzandaran, 13 times in Etišē's History and twice in Sebēos. Finally the title kaysr is only ever applied to the Roman emperor (34 times in the Buzandaran, 11 times in Łazar's History, six times in Ełišē's History and 36 times in Sebēos' History). Yet only once in the Buzandaran is kaysr linked directly to 'Romans' and never in the other three texts. Instead the Roman ruler is identified consistently as t'agawor Yunac', 'king of the Greeks,' across all four texts (46 times in the Buzandaran, seven times by Łazar, once by Ełišē and 17 times by Sebēos) and is never called 'king of the Romans.' By way of comparison, it is striking that book II of Patmut iwn Atuanic contains three references to the 'king of the Romans' - both t'agawor Hrovmayec 'woc' and t'agawor Horomoc' occur - as well as four references to kaysr Horo$m o c$ ', 'emperor of the Romans.' This marks a significant departure from the other four works and will be addressed more fully in the final section of this study. Finally whereas tagaworut iwn is applied to a range of worldly kingdoms and reigns, ar$k$ 'ayut iwn is reserved exclusively for the heavenly realm.

It is much easier to assess how the texts correspond and diverge in their use of specific terms than it is to establish why they do so. Nevertheless, whilst acknowledging the challenge, a number of tentative propositions may be advanced. Taking them in chronological sequence, the Buzandaran is the only composition in this study to represent the Arsacid kingdom of Armenia as a present reality and it is unsurprising to find that kings of Armenia feature very prominently in the text, twice as often as kings of Persia. It is however very noticeable that the same terms are applied to both kings of Armenia and Persia; neither ark'ayic ark'ay, nor tèr Areac', is used. This has the effect of establishing parity between the two kings within the imagined historical landscape. It also serves to diminish the Sasanian royal line by implying that it did not have the right to use the traditional Iranian title 'king of kings.' Arguments from silence are always problematic but the absence of this title is striking, given that it occurs in all the other compositions as well as being attested in the handful of sur-

48 Sebēos (cf. fn. 8) 39.10 - 19. Heraclius is identified as ark'ay for the first time at 39.24. 
viving third-century Middle Persian inscriptions commemorating Sasanian rulers. ${ }^{49}$ It is unclear whether this omission derives from the underlying epic traditions or whether it was devised by the late fifth-century compiler. One could make a case for either context. The purpose however seems clear, to deny recognition of Sasanian hegemony.

Łazar's History, by contrast, employs both ark'ayic'ark'ay and tēr Areac'. Indeed it is the only composition which uses the latter title for the Persian ruler. This is consistent with Łazar's stress on the notion of Ërān as a meaningful category of identity. $\mathrm{He}$ is at pains to stress that Armenians are not $\bar{e}$, members of the community of Ērānšahr. ${ }^{50}$ On five occasions, the phrase 'you Aryans' is employed in direct speech by an Armenian, with the evident purpose of differentiating 'us,' that is, Armenians. The first of these is spoken by Aršawir Kamsarakan before king Yazdgird II; the other four are spoken by Vahan Mamikonean, one to the Persian commander Mihran, two in the course of negotiations with Nixor Všnaspdat and one in the presence of king Vałarš. ${ }^{51}$ Łazar also uses the phrase Areac ew anareac', 'of Ërān and not-Ërān,' on six occasions. For Łazar, these terms defined those who belonged to different religious communities, those who were $\bar{e}$, Iranian, and those who were not, anerr. When Vahan begins to outline his settlement terms to Nixor, the first and most important of his demands is 'you allow us our ancestral and natural religion (zhayreni ew zbnik ōrēns mer) and that you do not make any Armenian man a mog,' that is, a Zoroastrian priest. $^{52}$ Thus for Łazar, Armenian identity designated a religious identity, one that was incompatible with those of Ërānšahr. It is striking that Armenian and Aryan also both express different genealogical roots, for whilst Armenians traced their origins back to the eponymous Hayk - the land of Armenia is ašxarh Hayoc - Aryans imagined themselves to be descended from the mythical rulers of Ayriana Vaejah, the homeland of Zoroaster. So when Nixor says to Vahan, 'Although you have not lived with me ašxarhakc'ut'ean bnut eamb,' a difficult phrase to translate, but literally meaning 'in a state of naturally sharing the same $a$ šxarh/šahr,' he seems to be saying

\footnotetext{
49 For discussion and partial translation of the inscription of Šapur II (r. 309-379 CE) at Naqš-i Rustam, see Dignas and Winter (cf. fn. 1) pp. 56-7. The Parthian text opens 'I, the Mazdā-worshipping god Šāpūr, King of Kings of the Aryans and non-Aryans....' For the late third-century Paikuli inscription, referring to Šapur's son Nerseh, see P.O. Skjærvø and H. Humbach, The Sasanian Inscription of Paikuli (Wiesbaden, 1983) p. 32: 'May the King of kings graciously move from Armenia hither to Ērānšahr'. See also J. Wiesehöfer, “'King of kings' and 'philhellên': kingship in Arsacid Iran”, in Aspects of Hellenistic Kingship, ed. P. Bilde et al. (Aarhus, 1996) pp. 55-66.

50 R.E. Payne, A State of Mixture. Christians, Zoroastrians, and Iranian Political Culture in Late Antiquity (Oakland CA, 2015) pp. 6-10 and 23-38.

51 Eazar (cf. fn. 8) 45.29; 75.14; 92.9 and 15; and 95.17; Thomson (cf. fn. 18) pp. 130, 194, $228-9$ and 235.

52 tazar (cf. fn. 8) 89.8; Thomson (cf. fn. 18) p. 221.
} 
that he and Vahan belong to different communities, that 'I, Nixor, am an Aryan, of the šahr of Ērān, and you, Vahan, are not. ${ }^{53}$

Yet we do not have to look very far to see that this distinction between Aryan and non-Aryan/Ērān and not-Ērān did not entail political or social exclusion. In the very next phrase, Nixor acknowledges that he had seen Vahan at court on many occasions. The distinction had not prevented members of the Armenian nobility from serving the 'King of kings' faithfully on the field of battle in the past. In book II of Łazar's History, Vardan Mamikonean is described by the venomous hazarapet Mihrnerseh as 'a man of courage, who assisted the lord of Ėān; the memory of his greatest actions persists in Ērānšahr and many military commanders and other Aryans with whom he fought also remember, and even the lord who is like a god has seen with his own eyes at Marvirot his love of valour. ${ }^{54}$ This seems to be recalling an unidentified campaign in the vicinity of Marv in Khurasan during which Vardan had performed valiantly in the sight of the Persian king. Furthermore, when addressing Nixor, Vahan states 'You are our natural lords and we are your natural subjects. ${ }^{55}$ At the turn of the century, therefore, Łazar accepted that the normal state of affairs was for Christian Armenians to serve non-Christian rulers. This is confirmed in a long concluding homily, delivered by the Armenian Catholicos, Yovhan Mandakuni. He declares: 'Lovers of the church, children of the Apostles, the price of Christ's blood, do not make your souls servants to worldly fear. Give to Caesar what is Caesar's and to God what is God's. In the churches, bless God and the Lord from the springs of Israel. Love the church and be loved by the church. The church has softened kings, tamed wild animals, made wolves into lambs, rendered you glorious, shamed the enemies of the truth. ${ }^{56}$ Within this passage therefore Yovhan is urging his flock to recognise the authority of worldly rulers, 'Caesar' in this instance to be understood uniquely as representing the Sasanian šahanšah.

Why did Łazar represent the conflict in terms of religious difference, pitting Christian Armenians against Zoroastrian Aryans? One solution is to see it as a deliberate attempt to sharpen what it meant to be Armenian at a time when it was under threat. The source of that threat is harder to determine. It could be that Łazar was conscious that members of the Armenian elite were at risk of compromising or rejecting their Christian heritage. It is striking that both Vardan and Vahan Mamikonean are depicted as abandoning their Christian beliefs, albeit under duress and for a short time only. ${ }^{57}$ One of the major themes of the History is to demonstrate, categorically, that those Armenians who apostatized, as several princes of Siwnik did, not only deprived themselves of their eternal future in heaven; they also found them-

53 Łazar (cf. fn. 8) 91.14; Thomson (cf. fn. 18) p. 226. Thomson translates this as 'Although you have not lived with me in a geographical sense....'

54 Łazar (cf. fn. 8) 44.2; Thomson (cf. fn. 18) p. 124.

55 Łazar (cf. fn. 8) 92.18; Thomson (cf. fn. 18) p. 230.

56 Łazar (cf. fn. 8) 100.8-9; Thomson (cf. fn. 18) p. 242.

57 Łazar (cf. fn. 8) 26.1-30 and 75.19-25; Thomson (cf. fn. 18) pp. 86-97 and pp. 195-6. 
selves permanently out of favour at the Persian court, becoming miserable emaciated figures, shamed and dishonoured. Staying faithful to Armenian Christian tradition brought spiritual and temporal rewards, as Vahan Mamikonean could vouch. It was possible to be a Christian and serve the Persian king.

On the other hand, it could be that Łazar was more concerned about members of the Armenian elite drifting away from the Armenian Church and towards the Church of the East with its separate hierarchy extending throughout the territories of Erānšahr and its dyophysite confession. The last two decades of the fifth century was a time of bitter confrontation between different Christian communities across the Persian kingdom, with prominent figures such as Barsauma of Nisibis and Simeon of Bēt Aršam on opposite sides of the conflict. Although it seems that accusations of violent persecution were only laid against Barsauma in later miaphysite texts, there is strong evidence from an Armenian source to suggest that Barsauma and others were able to use the apparatus of the state to remove their opponents from office or deprive them of property. ${ }^{58}$ It could be therefore that Eazar chose to reflect on the heroism of individual martyrs as well as collective action against an impious persecuting other as a means of sharpening the boundaries of what it meant to be an Armenian Christian at a time of sectarian tension.

For Łazar, the good Persian ruler was one who listened to the petitions of his Christian Armenian subjects in person and gave his permission for them to observe their religious traditions openly and without fear. Vałarš is portrayed granting all of Vahan's requests 'in writing and under seal, today and for evermore. ${ }^{59}$ Eazar also records Vahan saying to Vałarš 'your religion seems to us false and the babblings of mindless men. ${ }^{60}$ Statements such as these served Łazar's purposes in marking the boundaries between the religious communities but are most certainly not verbatim records of what Vahan said before Vałarš. On the other hand, given that Łazar was sponsored by Vahan to compose his History, it would have been foolish to include speeches that did not align with Vahan's own sentiments. We have no way of proving how much of this happened but we do need to bear in mind that the account of the negotiations and final settlement had to be plausible, given that they had taken place within living memory. And there are within the narrative several features which appear to reflect the actual process of reintegration. When Vahan approaches Nixor for the first time, he sounds battle trumpets and earns an immediate rebuke from Nixor for doing so. 'You are not acting in accordance with the practice of

58 T.W. Greenwood, "Oversight, Influence and Mesopotamian Connections to Armenia across the Sasanian and Early Islamic Periods", in Mesopotamia in the Ancient World. Impact, Continuities, Parallels, Melammu Symposia 7, ed. R. Rollinger and E. van Dongen (Münster, 2015) pp. 511-13. The canons of the Council of Dvin in 505/6 identify Acacius, Barsauma and others causing 'much trouble and distress' for the faithful 'before princes and judges.'

59 Łazar (cf. fn. 8) 95.25; Thomson (cf. fn. 18) p. 236.

60 Łazar (cf. fn. 8) 95.14; Thomson (cf. fn. 18) pp. 234-5. Sut, false; mardoc 'anmtac ' barbanǰmunk', babblings of mindless men. 
Erān but performing something new. From now on, you must observe and obey the practice of Ėān completely, for on campaign, only the sparapet [Mid. Pers. spāhbed] of Ērān presumes to enter the camp of Ērān with a trumpet; no-one else among the Persians would dare to take this liberty. ${ }^{\prime 61}$ Vahan concurs but in return demands that Nixor make him a servant of the lord of Ẽān, implying that he would not have acted in this way if he had been, perhaps even that he had done so deliberately as a public demonstration of his lack of relationship. Or again, when Vahan arrives at the court of Vałarš and has an audience before the king and all the nobility of Ėrān, Vałarš recalls the effort involved in Vahan's journey and so asks after his health in the most cordial fashion and expresses pleasure in some unspecified way but does not ask any further questions that day. ${ }^{62}$ This formal welcome echoes the first meetings between a Persian ambassador and Roman officials, including the emperor, described by the sixth-century Roman diplomat Peter the Patrician. ${ }^{63}$ So when Łazar reports at the end of the negotiation that Vałarš asked Vahan 'Are you content with us, did we behave rightly, is there need of anything else? Speak,' we should accept this as a formulaic speech to be delivered by the ruler on departure. ${ }^{64}$ Intriguingly, Vahan invites Vałarš to grant the title of tanuter of the Kamsarakan, that is, to vest the ancestral property of the Kamsarakan family in one person as tanuter, lord of the house, which he duly does. ${ }^{65}$ However Vałarš defers appointing someone to the same position within the Arcruni family 'until the men of that house have shown to us some service of merit and perform some labours of benefit to the lands of Ērān (i.e., Ėrānšahr).' Although Łazar's History is concerned primarily to define and defend the Armenian church, it also reveals that loyal service to the Persian šahanšah had practical consequences for leading members of the Armenian elite as they sought appointment and recognition as legal head of the family through the title of tanuter. As the Arcruni example shows, this could be withheld. We have no way of determining when this practice began, nor how long it persisted, but evidently it was current when Łazar was writing. Thus while Łazar's History seeks to establish what it is to be Aryan and what it is to be Armenian in opposition to one another, it also illustrates

61 Łazar (cf. fn. 8) 91.6-9; Thomson (cf. fn. 18) p. 225.

62 Eazar (cf. fn. 8) 95.3; Thomson (cf. fn. 18) p. 233.

63 Constantine Porphyrogennetos, The Book of Ceremonies, Byzantina Australiensia 18, 2 vols., tr. A. Moffat and M. Tall with reprint of the 1829 CSHB Greek edition edited by J.J. Reiske (Canberra, 2012) I.89-90. According to Peter, on arriving at Chalcedon, the Persian ambassador was to be greeted and questioned about his journey. At the first meeting in Constantinople, the magistros was to ask him 'about the health of his emperor, and then about the children of his emperor, and about the archons and about his own health and that of his household and about his journey, that he had not been troubled at all on the way.'

64 Łazar (cf. fn. 8) 96.7; Thomson (cf. fn. 18) p. 237.

65 For this practice and the legal significance of tanutēr, see T.W. Greenwood, "A Contested Jurisdiction: Armenia in Late Antiquity”, in Sasanian Persia. Between Rome and the Steppes of Eurasia, ed. E.W. Sauer (Edinburgh, 2017) pp. 206-9 and 211-12. 
other means by which Armenians participated in the political culture and institutions of Sasanian Persia.

As noted above, Ełišè's treatment of the events of 450/1 CE is very different to that of Eazar. ${ }^{66}$ Rather than viewing the conflict as originating in tensions within the house of Siwnik', Ełišē presents it as the outcome of longstanding animosity on the part of Yazdgird II towards his Christian subjects; he also situates it in the context of successful recent military action against the Romans. ${ }^{67}$ Eliše gives greater prominence to the role of the clergy - the holy Łewond gives an extended homily on the heroes of ancient Israel before the battle of Awarayr - and to the sufferings of the captives in Persia. Furthermore his narrative ends with a long study of the patient endurance of the wives and widows of the martyrs back in Armenia; there is no trace of Vahan Mamikonean, nor of the events of 482 which culminated in the settlement. As Cowe noted, the effect of these changes is to highlight the spiritual dimension of the revolt, producing 'a sharpening of focus and polarization of the opposing

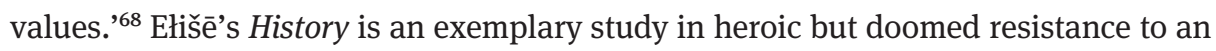
oppressive state in which the Armenian faithful stand alone. It lacks many of the complexities recorded in Łazar's History, the multiple betrayals and sudden switches in allegiance, the vast number of figures who emerge without warning and vanish again just as quickly, the incidental details which supply so much depth to the narrative - for example, that bishop Sahak was bilingual in Armenian and Persian but that catholicos Giwt was bilingual in Armenian and Greek, or that Vahan Mamikonean controlled gold mines but operated them in conjunction with a Syrian named Vriw who laid accusations against Vahan at court. ${ }^{69}$ Ełišē's History amplifies but it does so through the inclusion of speeches and at the expense of historical depth. From a terminological perspective, his work lacks the nuance of Łazar's History. By stressing Ērān and not-Ērān, and employing tēr Areac' for the Sasanian ruler, Łazar was able to highlight the different religious identities and communities without implying permanent political or social exclusion. Ełišè's History on the other hand presents a simple dichotomy between Persians and Armenians, a more straightforward but also more uncompromising construction of the relationship. One striking feature of Ełišè's History in terms of rulership is the anonymity of the Persian king

66 For a full comparison, see Thomson (cf. fn. 34) pp. 3-9.

67 For the military context, see Elišē (cf. fn. 8) 1.6 -9; Thomson (cf. fn. 34) pp. 61-2. Etišē reports that Yazdgird II 'attacked the land of the Greeks, struck as far as the city of Mcbin/Nisibis, devastated many districts of the Romans in his raiding, set fire to all the churches, amassed plunder and captives and terrified all the forces of the land.' Aside from the generic character of the account, Nisibis had been under Persian control since $363 \mathrm{CE}$ and while it was subjected to a short-lived siege by Roman forces in 421, this was quickly lifted. Etišē would not be alone in confusing the campaigns of 421 and 440/1, when the Persian raids seem to have been directed further north, in the vicinity of Theodosiopolis and Satala. Such confusion serves to distance his account from the middle of the fifth century. 68 Cowe (cf. fn. 38) p. 345.

69 For Sahak and Giwt, see Eazar (cf. fn. 8) 55.12 and 62.2; Thomson (cf. fn. 18) pp. 146 and 162; For Vahan and Vriw, see Łazar (cf. fn. 8) 65.9-20; Thomson (cf. fn. 18) pp. 170-1. 
Yazdgird II; t agawor is always used anonymously (103 times) whilst only eight of the 24 references to ark'ay also included the name of the king. This has the effect of imparting a timeless quality to the narrative and it may not be coincidental that Ełišē's History proved to be more influential on later generations than Eazar's History. ${ }^{70}$

\section{Sebēos and the Seventh Century}

Roman emperors and their rule obtain much greater prominence in the History attributed to Sebēos than the three earlier compositions. Far from being silent, peripheral figures, Maurice, Heraclius and Constans II participate throughout the narrative in action and in reported and direct speech, with different shades of approbation or criticism. Whereas the Roman ruler features 31 times in Eazar's History and just seven times in Ełišē's History, he is identified in Sebēos' History as t'agawor, kaysr or, for the first time, ark'ay, on no fewer than 163 occasions. This should come as little surprise, given the sustained Roman engagement with Armenia in the decades after 590 CE. We need, however, to be cautious when analysing their representation. By way of illustration, Maurice is portrayed as a ruler who described the Armenians as 'a perverse and disobedient race'; he is further identified as one who 'sought to preach Chalcedon in all the churches of the land of Armenia and unite them through the sacrament with his army. ${ }^{, 71}$ These comments are usually accepted as an accurate reflection of Maurice's attitude towards Armenia. Yet it is worth recalling that this whole work was assembled at least fifty years after these events and that the representation of Maurice may have been strongly informed by the compiler's own perception of Heraclius and Constans II. It is significant that a later passage records the role of the Greek forces in spreading their own liturgical practices, noting 'the Armenians never accepted the Roman [rite] in the sacrament of the body and blood of the Lord. ${ }^{72}$ Both the sentiment and the language used are proximate to the earlier references. The Maurice of Sebēos may therefore be articulating the present antipathy of the compiler towards Roman rule rather than representing how the figure of Maurice was viewed by Armenians at the end of the sixth century. This interpretation obtains additional support if the compiler was indeed the bishop who refused to take the sacrament with Constans II, for these all express confessional difference in terms of outward liturgical performance rather than inner theological conviction.

As noted above, the results of the terminological analysis of Sebēos' History are somewhat inconclusive. There is, for example, no greater association of the emperor with 'Roman-ness' and no displacement of the traditional Yunac', 'of the Greeks,' which remains ubiquitous. Constans II is titled tagawor Yunac' in the final entries

70 Cowe (cf. fn 38) pp. 343-4.

71 Sebēos (cf. fn.8) 15.4 and 19.3; Thomson and Howard-Johnson (cf. fn. 41) pp. 31, 37.

72 Sebēos (cf. fn.8) 45.31-2; Thomson and Howard-Johnson (cf. fn. 41) p. 113. 
at the end of the work. The only significant change is the application of arkay to the Roman ruler. This suggests that the meanings associated with it, previously restricted to Armenian and Persian kings, were transferred to the Roman emperor, or perhaps that the distinction between ark'ay and tagawor was in the process of breaking down. ${ }^{73}$ We have already seen that the late seventh-century core of book II of the History of Aluank' refers for the first time to the 'king of the Romans' and the 'emperor of the Romans.' The familiar t'agawor Yunac' continues to feature but there is also a unique reference to kaysr Yunac', the 'emperor of the Greeks. ${ }^{74}$ It seems that the conventions governing Armenian expressions of Roman rulership began to transform in the 650 s and continued to do so into the 680s.

A parallel development may be traced in a cluster of Armenian compositions completed, translated, or reworked at the end of the seventh century. These feature a renewed interest in Roman imperial and ecclesiastical history. A colophon tells us that abbot Grigor Jorap'orec i prepared a translation of the Life of Saint Sylvester in 677/8 CE for Nerseh the prince of Iberia and son-in-law of "the Kamsarakan. ${ }^{, 75}$ In 695/6 CE, at the request of tēr Nerseh Kamsarakan, apiwhipat patrik (Gr. árò

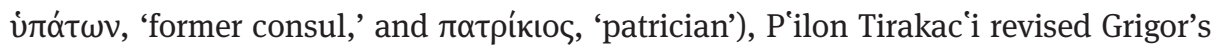
translation and used it as the introduction to his adapted version of an existing Armenian translation of the Ecclesiastical History of Socrates. ${ }^{76}$ In other words, P'ilon/ Philo revised and combined two separate texts which had already been translated into Armenian. The Life of Saint Sylvester fuses details from the saint's life with an account of the life of the emperor Constantine, his conversion and baptism by Sylvester - the bishop of Rome - and a long account of a debate between Christians and Jews which takes place in Rome. Socrates' Ecclesiastical History records church history within an imperial framework from the reign of Constantine to $439 \mathrm{CE}$ and the final years of the reign of Theodosius II. This is not the occasion to consider in any detail how P'ilon revised these two works but it is striking that he was commissioned to create a new account of fourth- and fifth-century imperial history from the time of Constantine and that what he produced coheres in several respects with Armenian tradition about their own conversion. P'ilon's reworking of the Life of Saint Sylvester amplifies the account of Constantine's persecution of Christians, the leprosy he con-

73 See fn. 47 above. The epigraphic evidence suggests that the distinction was maintained in the 630 s so it may be a reflection of the circumstances in which the compiler was working.

74 Patmut iwn Aluanic' (cf. fn. 45) II.25.6.

75 A.S. Mat'evosyan, Hayeren Jeragreri Hišatakaranner 5-12dd (Erevan, 1988) no. 29.

76 See R.W. Thomson, “The Armenian Versions of the 'Life of Sylvester”, Journal of the Society of Armenian Studies 14 (2005) pp. 55-139; and R.W. Thomson, The Armenian Adaptation of the Ecclesiastical History of Socrates Scholasticus, Hebrew University Armenian Studies 3 (Leuven, 2001). As Thomson notes in his introduction to the latter, at pp.11-12, the date and circumstances in which the first translation of Socrates' History was undertaken remain obscure. It is very unlikely that Socrates was a scholasticus; see H. Leppin, "The Church Historians I. Socrates, Sozomenus, and Theodoretus”, in Greek and Roman Historiography in Late Antiquity: Fourth to Sixth Century AD, ed. G. Marasco (Leiden and Boston MA, 2003) pp. 221-3. 
tracts as a result, and his baptism along with more than 12,000 others. ${ }^{77}$ These adaptations have the effect of making Constantine more like the Armenian king Trdat who also persecuted Christians, was afflicted by an incurable disease at God's command and was cured only once he had accepted Christianity and been baptised, with thousands of others. Here then the good ruler Constantine was reimagined in terms which allowed him to correspond more closely to the figure of Trdat. P'ilon's reworking of Socrates' Ecclesiastical History introduces much new material, some of which again adds an Armenian patina to the whole. It is however the final passages which are most instructive. P'ilon chose to include a revised version of Socrates' original Preface to Book VI in which he justified his work on the grounds that otherwise 'we' may fall away from a knowledge of the histories of saints, bishops and kings. Furthermore in his own colophon, P'ilon prayed that Nerseh would seek piety, pursuing righteousness, faith and love and seizing eternal life like 'the most pious king Theodosius (barepaštagoyn t'agaworn T'éodos),' and that he would 'follow the path of kings (čanaparh t'agaworac) like those of this History. ${ }^{, 78}$ In other words, P'ilon was maintaining that Roman emperors offered the best models of Christian rulership for Armenian princes such as Nerseh. This represents a significant shift in attitude from that displayed in the History attributed to Sebēos and stands in sharp contrast to the historical compositions which predate the seventh century, all of which are characterised by a disinterest in Roman rulership. So while it would be extremely unwise to extrapolate from these two later seventh-century adaptations and presume that they reflect views held throughout Armenia, they do point to an interest in refashioning fourth- and fifth-century history - the era of the Buzandaran and book I of Łazar's History - in completely new ways. Christian Roman rulership was now held to be worthy of emulation and could even be made to conform with features of historic Armenian kingship.

One other contemporary composition attests this reorientation. This work, known variously as Ananun Žamanakagrut iwn/Anonymous Chronicle or the History or Chronicle of Anania Širakac $i$ or P'ilon Tirakac $i$, is a complex, disjointed miscellany. ${ }^{79}$ It may be divided into two parts: firstly, a collection of discrete chronographical

77 Thomson (cf. fn. 76a) pp. 63-64.

78 Mat'evosyan (cf. fn. 75) no. 28; Thomson, (cf. fn. 76b) p. 229. Thomson has argued that P'ilon's scholarly undertaking should be set 'in the context of the aggressive self-definition of Armenians in the Muslim period following the last and unsuccessful attempt at reunion with Constantinople' (cf. fn. 76b, p. 40). It is however possible that the last decade of the seventh century was characterised by a range of Armenian responses to its imperial neighbour, including continuing relationship. $\mathrm{P}^{\mathrm{i}} \mathrm{i}$ lon's adaptations, stressing the similar conversion experiences of Constantine and Trdat and the worthiness of Theodosius II, appear to reflect a pro-Roman attitude.

79 Anonymous Chronicle, Ananum žamanakagrut ¿iwn, ed. B. Sargisean (Venice, 1904); A.G. Abrahamyan, Anania Širakac'u matenagrut yuně (Erevan, 1944) pp. 357-99; P'ilon Tirakac i, Žamanakagrut iwn, ed. A. Hakobyan, Matenagirk' Hayoc' 7th Century, vol. 5 (Ant ilias, 2005) pp. 899-969, which divides the text into three. For a study, see T.W. Greenwood, “'New Light from the East': Chro- 
extracts, largely deriving from works originally composed in Greek and including a freestanding sequence of Roman emperors from Julius Caesar to the thirtieth year of Heraclius (639/40 CE), suggesting that this was created during the reign of Constans II; and secondly, a synoptic ecclesiastical history, also composite, displaying close knowledge of the circumstances and decisions of church councils, structured around a second, different Roman imperial sequence and extending from the birth of Christ to the second year of Justinian II $\left(686 / 7\right.$ CE). ${ }^{80}$ Its limited engagement with the Armenian past, alongside the lack of a full translation, have together ensured that this work remains on the margins of study. Yet it merits further attention. By way of illustration, part II displays an interest in the affairs of the see of Alexandria down to the end of the fifth century before switching focus to conditions in Jerusalem during the reign of Justinian $\mathrm{I}^{81}$ The final notices reveal a surprising but unmistakable adherence to the monothelete formulation, castigating those who repudiated it at the Sixth Ecumenical Church Council in Constantinople in 680/1 CE. ${ }^{82}$ Intriguingly one substantial passage from the Anonymous Chronicle was incorporated in P'ilon's reworking of Socrates' Ecclesiastical History, at chapter $170 .^{83}$ This indicates that the two works came out of the same intellectual context; indeed it has been argued that P'ilon himself was responsible for both. For the purposes of this study, however, the two key features are that both parts of the Anonymous Chronicle contain imperial sequences, and that part II traces the history of the wider Roman church from a miaphysite and then a monothelete perspective, with minor Armenian intrusions, when one might have expected the opposite, that is, Armenian narratives and an Armenian-focused ecclesiastical history, with minor Roman intrusions. The Anonymous Chronicle attests sustained scholarly engagement with the Roman imperial past, chronology and ecclesiastical history, supporting the contention that the second half of the seventh century witnessed a transformation in Armenian attitudes towards Roman rulership. ${ }^{84}$

\footnotetext{
nography and Ecclesiastical History through a Late Seventh-Century Armenian Source”, JECS 16/2 (2008) pp. 197-254.

80 P'ilon Tirakac'i (cf. fn. 79) pp. 899-935 and pp. 935-969 respectively. In manuscript Matenadaran 2679, written in $981 \mathrm{CE}$, the freestanding list ends with Heraclius but Matenadaran 5254, copied in $1280 \mathrm{CE}$, adds 'Kostandianos, 28 years. In 118 of the Armenian Era,' which equates to 669/70 CE (p. 931 and n. 23). It remains unclear how this final notice came to be omitted by the scribe of M2679 but included in M5254; we cannot rule out the possibility that it reflects later revision.

81 Greenwood (cf. fn. 79) pp. 230, 236 for Alexandria; pp. 238-42 for Jerusalem.

82 P'ilon Tirakac'i (cf. fn. 79) pp. 967-9.; Greenwood (cf. fn. 79) pp. 245-7.

83 Greenwood (cf. fn. 79) pp. 249, for this and three other corresponding passages; Thomson (fn. 76b) p. 227.

84 It is striking that this era also witnessed pro-Roman sympathies being articulated in Aluank', where the head of the church, Nersēs Bakur, and Queen Spram were accused of praying for the emperor: see Patmut iwn Aluanic' (cf. fn. 45) III.5.3.
} 


\section{Conclusion}

In conclusion, late antique Armenian literature contains a wealth of representations of rulership, extending beyond the stereotypical 'impious' Persian monarch. By treating the four chosen historical compositions as separate discourses, as products of specific circumstances, a nuanced picture has emerged. In refusing to use the traditional title 'king of kings,' the Buzandaran promoted the notion of parity between Armenia and Sasanian kingship. Since the Armenian Arsacids were closely related to the Parthian dynasty, this subtle rejection of Sasanian hegemony is unsurprising. Łazar's History, on the other hand, offers the fullest expression of Armenian attitudes towards Sasanian rulership, highlighting religious difference but also revealing political integration. In Eazar's narrative, it is clear that being an Armenian Christian did not disqualify one from recognition by, or service to, the Sasanian king of kings. Armenian participation in the institutions and affairs of the Sasanian state was expected and typical; it was rebellion which was anomalous. By contrast, Ełišē's History constructed the relationship between Persians and Armenians as antagonistic, with service seemingly conditional on repudiation of Christian conviction and religious difference now a marker of political disloyalty. Ełišē presents Zoroastrian priests urging Yazdgird II to convert 'to one religion (i mi ōrēns) all the peoples and nations who are in your lordship. ${ }^{85}$ Yet as Thomson observed, this reflected Etišè's decision to reinterpret the Armenian revolt through the prism of the experience and fate of the Maccabees. ${ }^{86}$ The advice of the priests echoes the decision of Antiochus to send edicts throughout his realm instructing that 'all the inhabitants of the land should abandon their own religions and should subsist in one religion ( $\mathrm{mi}$ ōrēns)' (1 Mc 1:43). Ełišē's Yazdgird II was modelled, at least in part, on Antiochus, and its representation of Sasanian rulership was therefore distanced from both the historical figure of Yazdgird II and the Persian ruler of his own day, probably Khusro I. In this composition, the focus is on the reaction of the faithful to their circumstances - one that would suit a monastic context of production and circulation - and not on the creation of those circumstances, deemed to be out of their control. ${ }^{87}$

Roman emperors on the other hand remain on the margins of these three Armenian historical narratives. Whether or not this reflects genuine disengagement or confessional anxiety on the part of their clerical authors is unclear and likely to remain so. As the History attributed to Sebēos demonstrates, the demise of Sasanian Persia in the middle of the seventh century had an impact on how Roman emperors were titled and their presence in the narrative. This transformation can also be discerned in the Patmut 'iwn Atuanic 'through its use of the title king or emperor 'of the Romans'

85 Ełišē (cf. fn. 8) 1.21; Thomson (cf. fn. 34) p. 63.

86 Thomson (cf. fn. 34) pp. 11-16. The classic study remains R.W. Thomson, "The Maccabees in Early Armenian Historiography”, JThS 26 (1975) pp. 329-41.

87 Cowe (cf. fn. 38) pp. 352-6. 
rather than 'of the Greeks.' Several compositions from the final decades of that century reveal a willingness, on the part of some, to construct Roman emperors in new ways, by recasting the conversion experience of Constantine I to correspond to that of the Armenian King Trdat (Life of Saint Sylvester), by presenting the pious Theodosius II as a model Christian ruler for prince Nerseh Kamsarakan (Socrates' Ecclesiastical History) and by expressing time in terms of the sequence of Roman emperors (Anonymous Chronicle). It is impossible to assess the reception or the longevity of this positive projection of Roman rulership but it serves to remind us that a range of possible relationships existed for Armenian princes at the end of the seventh century, not least with the Roman emperor. 
